\section{Can Physics be Fun?}

THE Institute of Physics has recently produced a handsome book on humour and humanity in physics, which offers a rare opportunity to look at a large collection of pieces by physicists writing with a wider audience in mind $(A$ Random Walk in Science, an anthology compiled by R. L. Weber and edited by E. Mendoza, pp. 206 (Institute of Physics, Bristol) £4.75). The contents are distinctly variable - at the one end some fascinating insight into the prosecution of science, at the other ghastly laboured in-jokes. Pieces such as Jeremiah Horrox's description of his observation (sandwiched between preaching sermons at Mattins and Evensong) of the transit of Venus in 1639 and R. W. Wood's account of his encounter with Blondlot, of N-ray notoriety, are real delights and there are many others too. Donald Glaser's problems with getting the bubble chamber accepted and William Whewell's strictures against teaching modern discoveries to students are reminders that science never develops smoothly. For these the book can be recommended, but when physicists try to be funny, how banal they can be and how contrived their nonsense papers, bogus definitions and doggerel seem on paper.

Yet physics-in fact all the sciences-can produce no end of fun in the laboratory. The problem seems to be conveying this fun to others without diluting the impact.

Can humour be categorised? It is customary to speak of the juxtaposition of the ridiculous with the normal as the basis of humour-the virus that we illustrate on page 382 is a good example of this. Sometimes, however, the juxtaposition of the normal with the normal is just as funny, and there is potentially as big a laugh in the predictable happening as the unpredictable. This is perhaps particularly true when the predictable comes from, for instance, a group of people each of whom has individually the capability to behave unpredictably.

Words play a large part in all humour, of course, but apart from the very few really talented people who can use words for conscious humour-and they will not be looking for a career in science when the rewards are so great elsewhere--one can get great pleasure from the unconscious humour of words. Dr Spooner's accusation "you've hissed all my mystery lectures" is pure gold. Even the despicable Post Code, the ugly accretion that the British Post Office is trying, rather unsuccessfully, to foist on the public, has its lighter moments. The Natural Environment Research Council has the Post Code WC1H0AX.

Scientists are peculiarly prone to two extraordinarily persistent strains of humour-the pun and the limerick. It is difficult to find any extenuating circumstances for the pun despite its regular outings in the headlines of The Guardian. One would have thought that the towering achievement of the bilingual pun in the book Mots d'Heures, Gousses, Râmes would have silenced lesser perpetrators.

The limerick is an altogether healthier animal and it is not too difficult to see why it has such an appeal. It is palpably not poetry and so there is none of the embarrassment that would be attached to the combining of vulgarity with the immortal art form of, say, the sonnet. And yet it has the neatness of expression and the brevity of utterance of poetry. Relativity, with all its manifest absurdities to the man in the street, has been fertile territory for the limerick. Although the journey of the lady called Bright is well known to all physicists, it is sad to see the general decline and absence here of the marginally more plausible:

There once was a fellow called Fisk,

At fencing exceedingly brisk.

So fast was his action

The Fitzgerald contraction

Reduced his épée to a disk.

It would be impossible to write on humour in physics without giving a very honourable mention to Professor R. V. Jones, who rightly gets several pages to himself in the institute's book. He more than anyone else seems to be capable of capturing the laboratory joke and telling it amusingly. The Aberdeen chimney affair is every bit as funny as Gerard Hoffnung on the bricklayer's excuse. His Cambridge examination question does not make it into the book and deserves a wider circulation:

"It says in Proverbs, $30 \mathrm{vv}$ 18-19,

'There be three things which are too wonderful for me

Yea, four which I know not;

The way of an eagle in the air;

The way of a serpent upon a rock;

The way of a ship in the midst of the sea;

And the way of a man with a maid,'

Discuss any three."

\section{Years Ago}

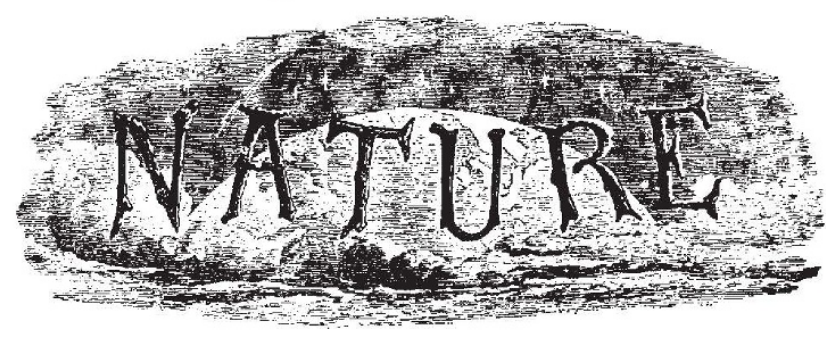

THE adult female Indian Rhinoceros, which has been in the Zoological Society's Gardens since July 1850, then not larger than a full-sized dog, died on Sunday last, having been ill for some time previously. The coldness of the weather and the fog were probably the exciting causes of its death, though no definite pathological changes have been found on post-mortem examination. There were no symptoms of senile decay.

From Nature, 9, 132, December 18, 1873. 